\title{
BMJ Global Health Willingness to comply with physical distancing measures against COVID-19 in four African countries
}

\author{
Mohamed Ali Ag Ahmed (D) , ${ }^{1,2}$ Birama Apho Ly, ${ }^{3}$ Tamba Mina Millimouno, ${ }^{4}$ \\ Hassane Alami, ${ }^{5}$ Christophe L Faye, ${ }^{6}$ Sana Boukary, ${ }^{7}$ Kirsten Accoe, ${ }^{8}$ \\ Wim Van Damme, ${ }^{8}$ Willem Van De Put, ${ }^{8}$ Bart Criel, ${ }^{9}$ Seydou Doumbia ${ }^{10}$
}

To cite: Ag Ahmed MA, Ly BA, Millimouno TM, et al. Willingness to comply with physical distancing measures against COVID-19 in four African countries. BMJ Global Health 2020;5:e003632. doi:10.1136/ bmjgh-2020-003632

Handling editor Seye Abimbola

Received 4 August 2020 Revised 5 September 2020 Accepted 8 September 2020

Check for updates

(c) Author(s) (or their employer(s)) 2020. Re-use permitted under CC BY-NC. No commercial re-use. See rights and permissions. Published by BMJ.

For numbered affiliations see end of article.

Correspondence to Dr Mohamed Ali Ag Ahmed; intoucaina@yahoo.fr

\section{INTRODUCTION}

The world is facing an unprecedented crisis related to the COVID-19 pandemic with many unknowns, which has led to much confusion and anxiety. ${ }^{1}$ Public health measures have for centuries been the cornerstone of the response to epidemics. ${ }^{2}$ Among them, physical distancing measures aim to reduce contact between infected and uninfected people. ${ }^{3}$ As part of the global COVID-19 response, they have been widely used to slow down the spread of the virus in several countries. Despite their overall acceptance, they have been poorly documented, particularly in Africa, and debates persist on their appropriateness and practicality in the context of lowincome countries. Many political, ethical and socioeconomic questions arise. ${ }^{4}$ This article describes the implementation of these measures in four West-African countries-Mali, Burkina Faso, Senegal and Guinea-and discusses people's willingness to comply with them. We draw on our experiences in crisis management through a collaborative project known as 'COVID-19 19 en Afrique Francophone'. ${ }^{5}$ The countries participating in this project were selected on the basis of a call for applications as part of an initiative by the Francophone Africa and Fragility Network, which brings together more than 100 national and international experts. ${ }^{6}$

\section{EPIDEMIOLOGICAL STATUS OF COVID-19}

In terms of population, Senegal has the highest number of cases, deaths and tested peoples. It is followed by Guinea concerning the number of cases. Burkina Faso reported the lowest number of cases and deaths and Mali the lowest number of tested people (table 1).

\section{Summary box}

Mali, Burkina Faso, Senegal and Guinea, four WestAfrican countries, have put in place several physical distancing measures that made it possible to contain the spread of COVID-19 in Western countries without too much questioning about their acceptability by their populations.

We describe these measures and discuss the importance of considering the socio-cultural, economic and political context to choose the most appropriate and effective measures.

We propose ways to explore strategies that are potentially better adapted to the African context.

The number of cases and deaths in the four countries is low compared with Western countries. ${ }^{7}$ However, no scientific evidence is available on the determinants of this difference. Meanwhile, many assumptions are provided. These assumptions include the low testing capacity, the difference in healthseeking behaviour patterns, the effectiveness of control measures, the sensitivity of the virus to heat and humidity, the young age of African populations, the crossed-immunity, the genetic factors and the previous exposure to coronavirus. ${ }^{7-9}$

\section{DIVERSITY IN PHYSICAL DISTANCING MEASURES} IN THE FOUR COUNTRIES

The main measures of physical distancing have been decreed at the national or local level in the four countries and consist of a mix of a ban on mass gatherings, border closures, curfews, quarantine of cities and reduction of working hours (table 2).

These measures were decreed relatively quickly, but have been gradually operationalised through a top-down approach. The decisions to implement them were taken 
Table 1 Overview of COVID-19 cases, deaths and tests by country as of 22 August 2020

\begin{tabular}{lcrrrrrr}
\hline Countries & Population & Cases & Deaths & Tests & Cases/1M pop & Deaths/1M pop & Tests/1M pop \\
\hline Mali & 20.325 .303 & 2667 & 125 & 32716 & 131 & 6 & 161 \\
Guinea & 13.178 .580 & 8876 & 53 & 18094 & 674 & 4 & 1373 \\
Senegal & 16.800 .813 & 12559 & 261 & 134349 & 748 & 16 & 7997 \\
Burkina Faso & 20.976 .858 & 1297 & 55 & 34845 & 62 & 3 & 1661 \\
\hline
\end{tabular}

Source : https://www.worldometers.info/coronavirus/ and Ministry of Health of Burkina Faso. pop, population.

either by the President of the Republic or ministers and sometimes by provincial or state governors to affirm a strong political will and to ensure their rapid application. However, application varied by the situation, ranging from coercion to simple recommendations. The vigour with which restrictions on gatherings were implemented seemed to vary from country to country. To prevent the 'import' of the virus, border closures and flight suspensions were decreed by all countries, except for special flights, cargo ships and medical evacuations. These measures had also proved to be successful in slowing down the spread of viruses in the previous SARS and Ebola epidemics. A curfew was introduced by all four countries, sometimes coupled with the declaration of a state of health emergency. Looking at the setup of quarantine measures within cities, unanimous approval had

Table 2 Physical distance measures and their implementation in the four countries

\begin{tabular}{llll}
\multicolumn{1}{c}{ Mali } & Senegal & Burkina Faso & Guinea \\
\hline $\begin{array}{l}\text { Declaration of the first } 24 \text { March 2020 } \\
\text { COVID-19 case (date) }\end{array}$ & 02 March 2020 & 09 March 2020 & 12 March 2020
\end{tabular}

Ban on mass gatherings
Interdiction of mass gatherings of more than 50 people. Collective prayers were prohibited but had poor compliance. Schools and universities closed 1 week before the first COVID-19 case. No interdiction of interurban transport. No closure of markets but regulation of opening hours.

\section{Interdiction of mass Interdiction of mass} gatherings of more than 50 gatherings of more than people. Closure of schools 50 people. Closure of and universities. Collective schools and universities. prayers were prohibited and had moderate compliance. Schools and universities closed some weeks after the first case. No interdiction of interurban transport. Closure of markets.

\begin{tabular}{|c|c|c|c|c|}
\hline Closure of borders & $\begin{array}{l}\text { Suspension of commercial } \\
\text { flights, followed by } \\
\text { complete closure of } \\
\text { borders } 1 \text { week before the } \\
\text { first COVID-19 case. }\end{array}$ & $\begin{array}{l}\text { Closure of borders } \\
3 \text { weeks after the first } \\
\text { COVID-19 case. }\end{array}$ & $\begin{array}{l}\text { Closure of borders } \\
\text { announced for } 2 \\
\text { renewable weeks. }\end{array}$ & $\begin{array}{l}\text { Closure of borders with all } \\
\text { high-risk countries who } \\
\text { had announced more than } \\
200 \text { COVID- } 19 \text { cases. }\end{array}$ \\
\hline Curfews & \multicolumn{4}{|c|}{$\begin{array}{l}\text { A curfew was introduced by all four countries according to various schedules, sometimes coupled with the } \\
\text { declaration of a state of health emergency. }\end{array}$} \\
\hline Quarantine of cities & $\begin{array}{l}\text { Quarantine was not } \\
\text { considered relevant. }\end{array}$ & $\begin{array}{l}\text { Only one quarantined } \\
\text { village: Boyinugal } \\
\text { (Tambacounda). }\end{array}$ & $\begin{array}{l}\text { Quarantine of all cities } \\
\text { reporting a COVID-19 } \\
\text { case. }\end{array}$ & $\begin{array}{l}\text { Only the capital city } \\
\text { (Conakry) partially } \\
\text { quarantined. }\end{array}$ \\
\hline $\begin{array}{l}\text { Reduction of working } \\
\text { hours }\end{array}$ & $\begin{array}{l}\text { Working hours were } \\
\text { reduced from 08:00. } \\
\text { to } 14: 00 \text {. Teleworking } \\
\text { and rearrangement } \\
\text { of workspaces were } \\
\text { recommended. }\end{array}$ & $\begin{array}{l}\text { Working hours were } \\
\text { reduced from 09:00 } \\
\text { to 15:00. Teleworking } \\
\text { and rearrangement } \\
\text { of workspaces were } \\
\text { recommended. }\end{array}$ & $\begin{array}{l}\text { Working hours were } \\
\text { reduced from 08:00 } \\
\text { to } 14: 00 \text {. Teleworking } \\
\text { and rearrangement } \\
\text { of workspaces were } \\
\text { recommended. }\end{array}$ & $\begin{array}{l}\text { No formal restrictions } \\
\text { by the government. } \\
\text { However, companies, } \\
\text { NGOs and institutions } \\
\text { adjusted their timetables } \\
\text { and operational modus, } \\
\text { to end the working day } \\
\text { at } 14: 00 \text {. Teleworking } \\
\text { and rearrangement } \\
\text { of workspaces were } \\
\text { recommended. }\end{array}$ \\
\hline
\end{tabular}

NGO, non-governmental organisation. 
not been reached. These measures define the restriction of all movement between the quarantined city and the rest of the country. Finally, some countries reduced the daily working hours to a health emergency. Looking at the setup of quarantine measures within cities, unanimous approval had not been reached. These measures define the restriction of all movement between the quarantined city and the rest of the country. Finally, some countries reduced the daily working hours to minimise contact between workers and allow them to return home before the time that the curfew began.

\section{WILLINGNESS TO COMPLY WITH PHYSICAL DISTANCING MEASURES IS UNCERTAIN}

As in high-income countries, the rationale for these measures given by the authorities was to slow down the spread of COVID-19, to 'flatten the curve' and thus enable health systems to cope with the influx of complicated cases. $^{2}{ }^{10}{ }^{11}$ Yet, despite the efforts made by these four countries, their current health systems are too weak to adequately respond to the needs. Therefore, these measures have encountered important constraints in these poorly prepared countries ${ }^{12}$ and are sometimes even considered to be counterproductive. ${ }^{11}$ They are indeed straining their already fragile and informal economies, leading to a significant loss of income for families. Additionally, these measures have had a strong impact on the existing social and cultural realities in particular, compromising their acceptability within the communities. They are likely to have potentially serious psychosocial consequences, to contribute to deprive many patients of care and to lead to political disturbances. ${ }^{11}$ Moreover, the ultimately limited benefits of these measures in reducing COVID-19-related mortality make it important to weigh their merits against their negative impacts.

On a completely different level, physical distancing measures have clearly not been successful in preventing contact between people in these countries. The willingness to comply with the populations and even by some of the authorities has not been optimal. For example, within the same country, only certain types of gatherings could be prohibited; however, prayers in mosques and churches could not be restricted due to the political weight of religious groups. In Mali, an international religious gathering, with thousands of participants, was able to take place in the region of Sikasso. Similarly in Senegal, a religious gathering in Tamba could not be banned. It was attended by thousands of worshipers including those from neighbouring countries, resulting in this region being declared a COVID-19 hotspot. Baptisms, weddings and Friday prayers were relocated to villages bordering The Gambia. In Burkina Faso, prayers in places of worship were not immediately banned and markets remained open for a long time.

Also, despite the ban on gatherings, legislative elections were maintained by the Malian authorities and a ballot was organised in Guinea. Giant public demonstrations were organised as part of political campaigns, resulting in some several candidates contracting COVID-19 and some deaths. Subsequently, the results of these polls were popularly reported in mass gatherings. In Mali, markets were never closed and public transport remained crowded.

The measures put in place in these countries could not prevent close contacts between people, particularly in residential housing and between neighbouring families, during commuting and in work environments.

Mali closed its borders before cases appeared, whereas the other three countries closed their borders only several days after the first cases appeared. Perhaps, this could explain why Mali was the last country to report its first cases. Even so, the closure of the borders seems more relevant early in the pandemic to reduce the risk of importing cases. Its sustainability can be questioned when community transmission is already taking place, given the huge risk of negative socioeconomic impact. The porous nature of the borders between neighbouring African countries also has its limitations to prevent movement, a reality that the Minister of Health of Mali acknowledged as well. ${ }^{13}$ Moreover, the ban on international travel may also constitute an obstacle to support the international response and preparedness operations for COVID-19. ${ }^{14}$

\section{A TIME OF ABRUPT BACK-PEDALLING}

Although the number of COVID-19 cases is still increasing, all four countries have revised some measures under popular pressure, the impossibility of enforcing them and their controversial impact. Burkina Faso reopened its schools and several big markets. The reopening of mosques and churches has been authorised. The quarantine has been lifted in all cities. The resumption of urban and interurban transport has been effective. The curfew timings have been reduced. In Mali, it has simply been lifted entirely. In Senegal, the reopening of places of worship and certain markets and shops has been authorised and examination classes were resumed. In Guinea, the curfew was lifted for towns in the interior of the country but was maintained for Conakry, Dubréka and Coyah (from 22:00 to 05:00) and gatherings of 20-30 persons were again authorised.

\section{CONCLUSION}

The low number of cases and deaths in the four countries included in this work can be explained by many factors. Also, several measures of physical distancing have been implemented to varying extents in these countries. These strategies are very similar to those applied in high-income countries, but the contexts are very different, which seems to have led to suboptimal results. ${ }^{11}$ Several factors such as the age structure of the population, the political and security stability and the capacity of the country to implement them need to be taken into account. Their importance in slowing down the spread of COVID-19 is beyond doubt; however, the negative socioeconomic impact on the population needs to be taken into account 
even more for poor countries. Indeed, the disruptions caused by these measures have a high cost for the countries concerned. ${ }^{11}$ Similarly, their potential to reduce mortality related to COVID-19 seems to be compromised by the weakness of the health systems in these countries. People's compliance with the measures implemented is further jeopardised by prevailing social, religious, political and economic norms. Finally, these measures were only partially implemented in these four countries, reducing their potential impact. They have generated popular uprisings, forcing the authorities to reconsider some of the decisions made without thinking about a real exit strategy. Indeed, as the spread of the virus continues, it is very difficult to decide when and how to gradually relax these measures. Experts should, therefore, agree on the most effective and realistic measures. Handwashing, although difficult in some contexts where populations do not even have access to safe drinking water, must be maintained. Similarly, situations conducive to superspreading of the virus can be reduced by implementing appropriate local solutions. ${ }^{11}$ Therefore, wearing masks should be considered as a priority strategy when physical distancing is not possible. Although less obvious to implement, other avenues such as mass screening, isolation of cases, contact tracing and quarantine must be quickly explored. This requires significant efforts to strengthen the existing health systems. Further research is essential to draw lessons from the implementation of these measures, identify best practices and evaluate the socioeconomic impact and their appropriateness in African contexts.

\author{
Author affiliations \\ ${ }^{1}$ University of Sherbrooke, Sherbrooke, Quebec, Canada \\ ${ }^{2}$ Faculty of Medicine, Pharmacy and Odonto-Stomatology of bamako, USTTB Mali, \\ Bamako, Mali \\ ${ }^{3}$ Faculty of Pharmacy, Université des Sciences des Techniques et des Technologies \\ de Bamako, Bamako, Mali \\ ${ }^{4}$ Centre National de Formation et de Recherche en Santé Rurale de Maferinyah, \\ Maferinyah, Guinea \\ ${ }^{5}$ Universite de Montreal, Montreal, Quebec, Canada \\ ${ }^{6}$ Migration Health Department, International Organization for Migration, Dakar, \\ Senegal \\ ${ }^{7}$ Management Sciences for Health, Ouagadougou, Burkina Faso \\ ${ }^{8}$ Department of Public Health, Institute of Tropical Medicine, Antwerpen, Belgium \\ ${ }^{9}$ Unit of Equity and Health - Department of Public Health, Institute of Tropical \\ Medicine, Antwerp, Belgium \\ ${ }^{10}$ UCRC, Bamako, Mali
}

Acknowledgements The authors thank the Collectivity platform for hosting our network 'AFRAFRA' and our collaborative project 'COVID-19 en Afrique Francophone', which allowed us to write this manuscript.
Contributors All authors have contributed to each stage of manuscript design and preparation. All authors approved the final version. MAAA is the guarantor of the article.

Funding The authors have not declared a specific grant for this research from any funding agency in the public, commercial or not-for-profit sectors.

Competing interests None declared.

Patient consent for publication Not required.

Provenance and peer review Not commissioned; externally peer reviewed.

Data availability statement All data relevant to the study are included in the article.

Open access This is an open access article distributed in accordance with the Creative Commons Attribution Non Commercial (CC BY-NC 4.0) license, which permits others to distribute, remix, adapt, build upon this work non-commercially, and license their derivative works on different terms, provided the original work is properly cited, appropriate credit is given, any changes made indicated, and the use is non-commercial. See: http://creativecommons.org/licenses/by-nc/4.0/.

\section{ORCID iD}

Mohamed Ali Ag Ahmed http://orcid.org/0000-0001-9374-871X

\section{REFERENCES}

1 Halperin DT. Coping with COVID-19: learning from past pandemics to avoid pitfalls and panic. Glob Health Sci Pract 2020;8:155-65.

2 Wilder-Smith A, Freedman DO. Isolation, quarantine, social distancing and community containment: pivotal role for old-style public health measures in the novel coronavirus (2019-nCoV) outbreak. J Travel Med 2020;27:taaa020.

3 Yezli S, Khan A. COVID-19 social distancing in the Kingdom of Saudi Arabia: BOLD measures in the face of political, economic, social and religious challenges. Travel Med Infect Dis 2020;101692:101692.

4 Tognotti E. Lessons from the history of quarantine, from plague to influenza A. Emerg Infect Dis 2013;19:254-9.

5 Chen N, Zhou M, Dong X, et al. Epidemiological and clinical characteristics of 99 cases of 2019 novel coronavirus pneumonia in Wuhan, China: a descriptive study. Lancet 2020;395:507-13.

6 AFRAFRA. Afrique francophone et fragilité, 2019. Available: https:// www.thecollectivity.org/fr/communities/reseau-afrique-francophonefragilite-afrafra

7 Bonnet E, Le Marcis F, Faye A, et al. The COVID-19 pandemic in Francophone West Africa from the first cases to responses in seven countries, 2020.

8 Van Damme W, Dahake R, Delamou A, et al. The COVID-19 pandemic: diverse contexts; different epidemics-how and why? BMJ Glob Health 2020;5:e003098.

9 Rice BL, Annapragada AV, Baker RE, et al. High variation expected in the pace and burden of SARS-CoV-2 outbreaks across subSaharan Africa. medRxiv 2020. doi:10.1101/2020.07.23.20161208. [Epub ahead of print: $24 \mathrm{Jul} 2020]$.

10 Preiser W, Van Zyl G, Dramowski A. COVID-19: getting ahead of the epidemic curve by early implementation of social distancing. S Afr Med J 2020;110:258.

11 Hodgins S, Saad A. Will the higher-income country blueprint for COVID-19 work in low- and lower middle-income countries? Glob Health Sci Pract 2020;8:136-43.

12 Dixon DL, Van Tassell BW, Vecchié A, et al. Cardiovascular considerations in treating patients with coronavirus disease 2019 (COVID-19). J Cardiovasc Pharmacol 2020;75:359-67.

$13 \mathrm{RFI}$. Coronavirus: au Mali les autorités déplorent la perméabilité des frontières, 2020. Available: https://www.rfi.fr/fr/afrique/20200324coronavirus-mali-autorit\%C3\%A9s-d\%C3\%A9plorent-perm\%C3\% A9abilit\%C3\%A9-fronti\%C3\%A8res

14 Lucero-Prisno DE, Adebisi YA, Lin X. Current efforts and challenges facing responses to 2019-nCoV in Africa. Glob Health Res Policy 2020;5:21. 